OPEN ACCESS

Edited by:

David Pozo,

University of Seville, Spain

Reviewed by:

Even Fossum,

Oslo University Hospital, Norway

Xin Li,

China Agricultural University, China

*Correspondence:

Pilar Rivera-Gil

pilar.rivera@upf.edu

Sira Defaus

sira.defaus@upf.edu

Specialty section:

This article was submitted to

Molecular Innate Immunity,

a section of the journal

Frontiers in Immunology

Received: 23 March 2021

Accepted: 24 May 2021

Published: 16 June 2021

Citation:

An W, Defaus S, Andreu D and Rivera-Gil P (2021) In Vivo Sustained Release of Peptide

Vaccine Mediated by

Dendritic Mesoporous

Silica Nanocarriers.

Front. Immunol. 12:684612. doi: 10.3389/fimmu.2021.684612

\section{In Vivo Sustained Release of Peptide Vaccine Mediated by Dendritic Mesoporous Silica Nanocarriers}

\author{
Weiteng $A n^{1}$, Sira Defaus ${ }^{2 *}$, David Andreu ${ }^{2}$ and Pilar Rivera-Gil ${ }^{1 *}$ \\ 1 Integrative Biomedical Materials and Nanomedicine Laboratory, Department of Experimental and Health Sciences, \\ Universitat Pompeu Fabra, Barcelona, Spain, ${ }^{2}$ Proteomics and Protein Chemistry Unit, Department of Experimental and \\ Health Sciences, Universitat Pompeu Fabra, Barcelona, Spain
}

Mesoporous silica nanoparticles have drawn increasing attention as promising candidates in vaccine delivery. Previous studies evaluating silica-based vaccine delivery systems concentrated largely on macromolecular antigens, such as inactivated whole viruses. In this study, we synthesized dendritic mesoporous silica nanoparticles (DMSNs), and we evaluated their effectiveness as delivery platforms for peptide-based subunit vaccines. We encapsulated and tested in vivo an earlier reported foot-and-mouth disease virus (FMDV) peptide vaccine $\left(B_{2} T\right)$. The $B_{2} T @ D M S N s$ formulation contained the peptide vaccine and the DMSNs without further need of other compounds neither adjuvants nor emulsions. We measured in vitro a sustained release up to $930 \mathrm{~h} . \mathrm{B}_{2} \mathrm{~T} @ \mathrm{DMSNs}-57$ and $\mathrm{B}_{2} \mathrm{~T} @ \mathrm{DMSNs}$ 156 released $23.7 \%(135 \mu \mathrm{g})$ and $22.8 \%(132 \mu \mathrm{g})$ of the total $B_{2} T$. The formation of a corona of serum proteins around the DMSNs increased the $\mathrm{B}_{2} \mathrm{~T}$ release up to $61 \%$ (348 $\mu \mathrm{g} / \mathrm{mg})$ and $80 \%$ (464 $\mu \mathrm{g} / \mathrm{mg})$ for $\mathrm{B}_{2} \mathrm{~T} @ \mathrm{DMSNs}-57$ and $\mathrm{B}_{2} \mathrm{~T} @ \mathrm{DMSNs}-156$. In vitro results point out to a longer sustained release, assisted by the formation of a protein corona around DMSNs, compared to the reference formulation (i.e., $\mathrm{B}_{2} T$ emulsified in Montanide). We further confirmed in vivo immunogenicity of $\mathrm{B}_{2} \mathrm{~T} @ \mathrm{DMSN}$ s in a particle size-dependent manner. Since $B_{2} T @ D M S N$ s elicited specific immune responses in mice with high lgG production like the reference $\mathrm{B}_{2} \mathrm{~T}^{\mathrm{O}}$ Montanide ${ }^{\mathrm{TM}}$, self-adjuvant properties of the DMSNs could be ascribed. Our results display DMSNs as efficacious nanocarriers for peptidebased vaccine administration.

Keywords: dendritic mesoporous silica nanoparticles, peptide vaccines, sustained and controlled release, foot-and-mouth disease virus, nanovaccine, immunogenicity, adjuvancy

\section{INTRODUCTION}

Peptide-based vaccines are considered an attractive alternative strategy to overcome many of the limitations of conventional (inactivated, attenuated) whole virus-based vaccines (1-3). They present advantages such as reduced toxicity, good definition of $\mathrm{T}$ - and B-cell epitopes for targeted immune responses, cost-effective scale up manufacturing processes, easy handling, storage, and transport (1, $4,5)$. These advantages have prompted the progress of many peptide-based vaccines to different preclinical and clinical stages $(1,6,7)$. Nevertheless, peptide-based vaccines tend to be poorly 
immunogenic usually requiring adjuvants, multivalency, and/or delivery systems to become more effective in vivo. Adjuvants of different kinds, such as aluminum hydroxide, mineral salts, water-oil emulsions, or liposome-based formulations have been developed to enhance efficacy (7). Although these strategies can boost to a certain extent the low immunogenicity of peptidebased vaccines, only a limited number are approved for human and animal applications due to their not well-established mode of action, as well as to other related toxicity and safety issues $(8,9)$.

In the last decade, the field of nanovaccines has gained maturity (10-13). Nanoparticles, especially synthetic ones made of polymers, phospholipids, metal, carbon, or silica (14) among other compositions have been extensively studied for vaccine applications ref $(1,9,15,16)$. Within the variety of nanomaterials used for vaccine delivery, mesoporous silica nanoparticles (MSNs), especially dendritic mesoporous silica nanoparticles (DMSNs), are emerging as promising vaccine delivery platforms because of their versatile formulation, boosting abilities, lack of side effects, and depot effect. They have unique central-radial pore structures with large pore sizes (17-19) and are characterized by low cross-linking silica frameworks with fast degradability rate in vivo (20). Studies on DMSNS show their enhanced loading capacity, sustained release profile, easy surface functionalization, and potential adjuvant activity $(21,22)$. Furthermore, DMSNs have shown effective immune potentiation in vivo, inducing strong humoral and cellular immune responses against target antigens (23-25). The majority of studies on MSNs-based vaccine delivery systems are focused on carrying large-size immunogens, such as bacterial recombinants, viral capsid proteins and OVA- and BSAconjugated model vaccines (26-29), whereas few papers explore their use to carry smaller biomolecules, such as peptides in subunit vaccines.

In this study, we extend the use of DMSNs to delivery platforms for peptide-based vaccines and evaluate their in vivo effectiveness. We have encapsulated a peptide construct named $\mathrm{B}_{2} \mathrm{~T}$, which confers full protection against foot-and-mouth disease virus (FMDV) in swine $(30,31)$. Previous publications of the authors have shown that inclusion of a T-cell epitope in the $\mathrm{B}_{2} \mathrm{~T}$ construct provides a rather powerful $\mathrm{T}$-cell response (lymphoproliferation, $\gamma$-interferon production) $(31-33) . \mathrm{B}_{2} \mathrm{~T}$ is currently administered emulsified with Montanide ${ }^{\mathrm{TM}}$ ISA $50 \mathrm{~V} 2$ $\mathrm{W} / \mathrm{O}$ (water in oil) (i.e., $\mathrm{B}_{2} \mathrm{~T} @$ Montanide ${ }^{\mathrm{TM}}$ ). This formulation has some drawbacks. For instance, there are several studies reporting unacceptable local reactions toward the Montanide adjuvant (34). Moreover, Montanide requires a dedicated emulsification procedure for each antigen which add complexity to its industrial production (35). To overcome these challenges, we have explored the use of DMSNs loaded with $\mathrm{B}_{2} \mathrm{~T}$ as nanovaccine against FMDV. Briefly, we have synthesized DMSNs of different sizes $(57 \pm 9 \mathrm{~nm}$ and $156 \pm 10$ $\mathrm{nm}$ ) and have loaded them with $\mathrm{B}_{2} \mathrm{~T}$, naming the resulting nanoformulation $\mathrm{B}_{2} \mathrm{~T} @ \mathrm{DMSNs}$. Both sizes exhibited high $\mathrm{B}_{2} \mathrm{~T}$ loading capacities $(570 \mu \mathrm{g} / \mathrm{mg}$ for DMSNs-57 and $580 \mu \mathrm{g} / \mathrm{mg}$ for
DMSNs-156) and an in vitro sustained $\mathrm{B}_{2} \mathrm{~T}$ release profile over 930 h. Furthermore, RAW 264.7 macrophage cells efficiently internalized the fluorescent version of both nanoformulations in a size-dependent manner. Finally, we have confirmed a specific immune response with high IgG production upon vaccination of outbred Swiss mice (Swiss ICR-CD1) with two doses of $\mathrm{B}_{2} \mathrm{~T} @$ DMSNs, obtaining similar antibody titers than those elicited by the previous gold standard $\mathrm{B}_{2} \mathrm{~T} @$ Montanide ${ }^{\mathrm{TM}}$.

\section{MATERIALS AND METHODS}

For a detailed description of the procedures and more results, we refer the readers to the Supporting Information File.

\section{Synthesis and Characterization of DMSNs-57 and DMSNs-156}

The DMSNs with a diameter of $156 \mathrm{~nm}$ (designated as DMSNs156) were synthesized using a modified version of a previously reported method (17). Briefly, $136 \mathrm{mg}$ TEA were added to $50 \mathrm{~mL}$ Milli-Q water and stirred at $500 \mathrm{rpm}, 80^{\circ} \mathrm{C}$ for $0.5 \mathrm{~h}$. Then, 760 $\mathrm{mg}$ CTAB and $250 \mathrm{mg}$ sodium salicylate (NaSal) was added to the above solution and stirred for another $1 \mathrm{~h}$. Next, $4 \mathrm{ml}$ TEOS was added dropwise to the solution under stirring, which continued overnight. The products were collected by centrifugation at $12,000 \mathrm{rpm}$ for $10 \mathrm{~min}$ and washed three times with ethanol. Then, the collected products were extracted three times with $80 \mathrm{ml}$ of methanol solution containing $4.5 \mathrm{ml}$ of $\mathrm{HCl}(37 \%)$ at $65^{\circ} \mathrm{C}$ for $6 \mathrm{~h}$ to remove the template. Finally, the nanoparticles were dried in vacuum at room temperature overnight. DMSNs with a diameter of $57 \mathrm{~nm}$ (designated as DMSNs-57) were synthesized following the abovementioned method except for decreasing the amount of structure directing agent NaSal from 250 to $83 \mathrm{mg}$.

The structure of both DMSNs types was imaged with a transmission electron microscope (TEM, JEOL JEM1010) at an acceleration voltage of $80 \mathrm{kV}$. TEM specimens were prepared by evaporating one drop of ethanolic nanoparticle solution on Ted Pella Formvar carbon-coated copper grids. The z-potential and hydrodynamic diameter of the samples was determined in a Malvern Zetasizer ZS instrument at $25^{\circ} \mathrm{C}$. Samples were dispersed in water and transferred into disposable polystyrene cuvette. The given values are the average of triplicate readings.

See de Supplementary File (section $\$ S I-1.1$ ) for complementary information.

\section{$\mathrm{B}_{\mathbf{2}} \mathrm{T}$ Synthesis}

The dendrimeric $\mathrm{B}_{2} \mathrm{~T}$ immunogen was produced as described earlier (31), by conjugation of 2 copies of the B-cell epitope moiety to a maleimide-functionalized T-cell epitope. The conjugation reaction was clean and practically quantitative, and the resulting branched peptide was satisfactorily characterized by HPLC and mass spectrometry. See section $\$ S I-1.2$ for complementary information and section $\$ S I-2.1$ for the synthesis of fluoro- $\mathrm{B}_{2} \mathrm{~T} @ \mathrm{DMSNs}$. 


\section{$\mathrm{B}_{2}$ T Loading in DMSNs-57 and DMSNs-156 and Quantification of Peptide Loading}

We followed the same methodology to load $\mathrm{B}_{2} \mathrm{~T}$ into both DMSNs sizes. The resulting products were named, $\mathrm{B}_{2} \mathrm{~T} @$ DMSNs-57 and $\mathrm{B}_{2}$ T@DMSNs-156. Briefly, $1.5 \mathrm{mg} \mathrm{B} \mathrm{B}_{2} \mathrm{~T}$ and 2.0 mg DMSNs were mixed in 2.0 mL DPBS buffer solution ( $\mathrm{pH} 7.4$ ) and then properly dispersed by sonication for $5 \mathrm{~min}$. The resulting mixture was gently shaken at $200 \mathrm{rpm}$ for $5 \mathrm{~h}$ at RT. Afterward, the products were separated by centrifugation at $12,000 \mathrm{rpm}$ for $10 \mathrm{~min}$ and washed twice with PBS. $\mathrm{B}_{2} \mathrm{~T}$ encapsulation efficiency (EE\%) was defined as follows:

$$
\begin{aligned}
& B_{2} T \text { encapsulation efficiency }(E E \%) \\
& \quad=\left(\text { weight of loaded } B_{2} T / \text { weight of total } B_{2} T\right) \times 100 \%
\end{aligned}
$$

where the amount of loaded $\mathrm{B}_{2} \mathrm{~T}$ was determined by subtracting the free $\mathrm{B}_{2} \mathrm{~T}$ in the supernatant from the total amount, and the amount of free $\mathrm{B}_{2} \mathrm{~T}$ in the supernatant was calculated based on the $\mathrm{B}_{2} \mathrm{~T}$ calibration curve obtained in DPBS (section $\$ S I-1.3$, Figure SI-3). See section $\$ S I-1.4$ for complementary information on the impact of key parameters (ionic strength, peptide structure, and DMSNs charge) on the loading efficiencies, and section $\$ S I-2.1$ for the loading of fluoro- $\mathrm{B}_{2} \mathrm{~T}$ into DMSNs.

\section{$\mathrm{B}_{2} \mathrm{~T}$ Calibration Curve}

$\mathrm{A} \mathrm{B}_{2} \mathrm{~T}$ stock solution $(1,000 \mu \mathrm{g} / \mathrm{ml})$ was prepared by dissolving 2 mg lyophilized $\mathrm{B}_{2} \mathrm{~T}$ powder in $2 \mathrm{ml}$ DPBS. From this stock solution serial dilutions in DPBS $(31.3,62.5,125,250$, and 500 $\mu \mathrm{g} / \mathrm{ml}$ ) were prepared and measured on a Biochrom ${ }^{\mathrm{TM}}$ Ultrospec 2100 Pro UV/Vis spectrophotometer using a quartz cuvette with a $1-\mathrm{cm}$ path length (with DPBS as blank). The calibration curve was constructed by plotting the absorbance at $225 \mathrm{~nm}$ against the corresponding $\mathrm{B}_{2} \mathrm{~T}$ concentrations. See section $\$ S I-1.3$ for complementary information.

\section{$\mathrm{B}_{\mathbf{2}} \mathrm{T}$ Release Kinetics From the DMSNs}

Release experiments were carried out in $1.5 \mathrm{ml}$ Eppendorf tubes containing $1.0 \mathrm{mg}$ DMSNs loaded with $\mathrm{B}_{2} \mathrm{~T}$ and $1.0 \mathrm{ml}$ DPBS (pH 7.4). Samples were gently shaken at $37^{\circ} \mathrm{C}$ and, at predetermined time points, the suspension was centrifuged at $12,000 \mathrm{rpm}$ for $10 \mathrm{~min}$. We took the supernatant and measure the absorbance $(225 \mathrm{~nm})$ of $\mathrm{B}_{2} \mathrm{~T}$ released. The procedure was repeated for each time point and for both DMSNs. Fresh DPBS (same volume than aliquot of supernatant taken) was added to redisperse the pellet. All release measurements were performed in duplicate.

\section{Imaging the Cellular Uptake of $\mathrm{B}_{\mathbf{2}}$ T@DMSNs}

RAW 264.7 cells in RPMI 1640 medium (containing 2 mM Lglutamine, $10 \%$ heat-inactivated FBS, and $1 \%$ penicillin and streptomycin) were seeded in Ibidi $\mu$-slide 8 well at a density of $5.0 \times 10^{4}$ cells/well. Cells were incubated at $37^{\circ} \mathrm{C}$ in an atmosphere of $5 \% \mathrm{CO}_{2}$ for $24 \mathrm{~h}$. Then, $30 \mu \mathrm{g} / \mathrm{ml}$ of fluoro$\mathrm{B}_{2} \mathrm{~T} @ \mathrm{DMSNs}$ was added to the cells. Following 0.5, 1, 2, 4, 8, and $16 \mathrm{~h}$ incubation, cells were washed three times with PBS, and fresh growth medium containing CellMask deep red plasma membrane was added and incubated for $8 \mathrm{~min}$. After three washes with PBS, fresh PBS was added, and cells were imaged by confocal laser scanning microscopy (CLSM). See section $\$ S I-2.2$ for complementary information.

\section{Flow Cytometry Analysis of Cellular Uptake}

RAW 264.7 cells were seeded in six-well plates in RPMI 1640 medium (containing $2 \mathrm{mM}$ L-glutamine, 10\% heat-inactivated FBS, and $1 \%$ penicillin and streptomycin) at a density of $1.0 \times 10^{6}$ cells/well. Cells were incubated at $37^{\circ} \mathrm{C}$ in an atmosphere of $5 \%$ $\mathrm{CO}_{2}$ for $24 \mathrm{~h}$. Then, $30 \mu \mathrm{g} / \mathrm{ml}$ fluoro-B 2 T@DMSNs was added. Following $0.5,1,2,4,8$, and $16 \mathrm{~h}$ incubation, cells were washed three times with PBS, new PBS was added, and cells were carefully detached from the plates with a Falcon cell scraper. The collected cells were transferred to tubes, were placed in ice, and the nuclear dye, DAPI was added to a final concentration of $1.0 \mu \mathrm{g} / \mathrm{ml}$, and incubated for $2 \mathrm{~min}$. The labelled cells were then measured by flow cytometry (FC) in a BD LSRFortessa X-50 flow cytometer. The mean fluorescence intensity (MFI) and percentage of cells with a positive fluorescent signal compared to the control (untreated cells) were determined on 5,000 gated single-living cells. FACS data were processed by the method described in section $\$ S I-2.3$.

\section{Mice Immunization}

Experiments were carried out in the animal facility of the CSIC Center for Research and Development (CID-CSIC), in agreement with EU (Directive 2010/63/EU on the protection of animals used for scientific purposes) and domestic (Real Decreto $53 / 2013$ ) regulations. The protocol to produce antibodies was in accordance with institutional guidelines under a license from the local government (DAAM 7463) and was approved by the Institutional Animal Care and Use Committee at the CID-CSIC.

All formulations were prepared on the day of injection. Mice were randomized into groups and inoculated by two subcutaneous injections over the interscapular area at day 0 and day 21 . All mice were euthanized at day 40 by carbon dioxide inhalation. Animals were monitored three times per week for health during the study.

To assess immunogenicity of $\mathrm{B}_{2} \mathrm{~T} @ \mathrm{DMSN}$ in mice, two trials were performed (section $\$ S I-3$ ). In the first one, mice were divided into three groups as shown in Table SI-1. The first group was the positive control group (4 mice) which was immunized with $200 \mu \mathrm{l}$ of Montanide ISA 50V2 emulsion containing $100 \mu \mathrm{g} \mathrm{B} \mathrm{B}_{2} \mathrm{~T}$ ( $\mathrm{B}_{2} \mathrm{~T} @ M_{\text {Montanide }}{ }^{\mathrm{TM}}$ ), following earlier studies (30); the second (six mice) and third (four mice) groups were the sample groups. The second group was treated with 100 $\mu \mathrm{g} \mathrm{B}_{2} \mathrm{~T}$ loaded in DMSNs-156 (B $\left.\mathrm{B}_{2} \mathrm{~T} @ \mathrm{DMSNs}-156\right)$ in $200 \mu \mathrm{l}$ DPBS, and the third group was treated with the same amount of DMSNs alone (163 $\mu \mathrm{g}$ DMSNs-156) in $200 \mu \mathrm{l}$ DPBS. All groups were boosted at day 21. Blood samples were collected before vaccination (day 0) and at days 14, 20 (pre-boost), and 40 (euthanize, sample obtained by cardiac puncture). In the second trial, aimed at assessing the impact of DMSNs size on 
mice immunization, mice were divided into three groups as shown in Table SI-2. The first group was again the positive control group $\left(\mathrm{B}_{2} \mathrm{~T} @ M\right.$ Montanide ${ }^{\mathrm{TM}}$; three mice). The second (five mice) group was treated with the formulation $\mathrm{B}_{2} \mathrm{~T} @ \mathrm{DMSNs}-57$ and the third (five mice) group with $\mathrm{B}_{2} \mathrm{~T} @ \mathrm{DMSN}$-156. All mice were treated with the same dose of peptide vaccine $\left(100 \mu \mathrm{g} \mathrm{B}_{2} \mathrm{~T}\right)$. Blood sample collection was extended until day 80 , to study the long-term immune effect of $\mathrm{B}_{2}$ T@DMSNs.

\section{Detection of Specific Anti-B ${ }_{2}$ T Antibodies by ELISA}

Specific antibodies were detected by enzyme-linked immunosorbent assay (ELISA). 96-well Costar ${ }^{\circledR}$ plates were coated with $50 \mu \mathrm{B}_{2} \mathrm{~T}(15.4 \mu \mathrm{g} / \mathrm{ml})$ in bicarbonate/carbonate coating buffer $(0.05 \mathrm{M}, \mathrm{pH} 9.6)$ and incubated at $4^{\circ} \mathrm{C}$ overnight. After washing three times with DPBS, $50 \mu \mathrm{l}$ of diluted serums (two-fold dilution series of each collected serum sample were prepared, starting at $1 / 150$, and each dilution sample in duplicate) were incubated for $1 \mathrm{~h}$ at $37^{\circ} \mathrm{C}$, followed by four DPBS washes. Pre-immune sera from mice were used as negative controls. Next, $50 \mu \mathrm{l}$ of a 1:4,000 dilution of HRP-labeled rabbit anti-mouse IgG were added and incubated for $1 \mathrm{~h}$ at $37^{\circ} \mathrm{C}$ followed by five washings with DPBS. Then, $100 \mu \mathrm{l}$ of TMB substrate solution was added for $20 \mathrm{~min}$ at RT in the dark. Finally, the reaction was stopped by adding $100 \mu \mathrm{l}$ of $1 \mathrm{M} \mathrm{H}_{2} \mathrm{SO}_{4}$. The optical density (OD) of the samples was measured in an ELISA reader (BioRad, CA, USA) at $450 \mathrm{~nm}$. Titers in a $\log 10$ scale were expressed as the reciprocal of the last dilution giving the absorbance recorded in the control wells (serum at day 0) plus 2 SD. See section $\$ S I-3.2$ for complementary information on the individual response of each mice to the treatment.

\section{Statistical Analysis}

Differences among $\mathrm{B}_{2} \mathrm{~T} @ D M S N s$-immunized groups in $\mathrm{B}_{2} \mathrm{~T}$ antibody titers were analyzed by one-way ANOVA, followed by Tukey's post-hoc comparisons tests. Values are cited in the text as means \pm SD. All $\mathrm{p}$ values are two-sided, and $p$ values < 0.05 were considered significant. Statistical analyses were conducted using GraphPad Prism Software 5.0 (San Diego, CA, USA).

\section{RESULTS}

\section{DMSNs Synthesis and Physicochemical Characterization}

TEM measurements showed that both types of DMSNs have an inorganic core diameter of $57 \pm 9 \mathrm{~nm}$ (DMSNs-57) and $156 \pm 10$ nm (DMSNs-156) (Figure 1A, B; $\$ S I-1.1$, Figures SI-1A-D). DLS measurements indicated that the averaged hydrodynamic diameter of DMSNs-57 was $75 \mathrm{~nm}$ with a polydispersity index (PDI) of 0.060 and the averaged hydrodynamic diameter of DMSNs-156 was $227 \mathrm{~nm}$ with a PDI of 0.061 (Figure 1C; $\$ S I-$ 1.1, Figure SI-1.E). The low PDIs for both nanoparticles demonstrate excellent monodispersity and uniformity which are consistent with TEM images. As expected, the DLS measurement showed higher size values for the DMSNs than those measured by TEM. This is due to the DMSNs' surface hydration in aqueous solution (36). The z-potential values of DMSNs-57 and DMSNs-156 were $-30.2 \mathrm{mV}$ and $-37.1 \mathrm{mV}$, respectively (Figure 1C). These results indicate colloidal stability and homogenous size distribution.

\section{Loading $B_{2} T$ Vaccine Into Differently Sized DMSNs (B $\mathrm{B}_{2} \mathrm{~T} @ \mathrm{DMSNs}$ ) and In Vitro Characterization of $\mathrm{B}_{\mathbf{2}} \mathrm{T}$ Release Kinetics}

After synthesizing DMSNs-57 and DMSNs-156, we performed their loading with the $\mathrm{B}_{2} \mathrm{~T}$ peptide vaccine (see section $\$ S I-1.2$, Figure SI-2 for $\mathrm{B}_{2} \mathrm{~T}$ structure). The $\mathrm{B}_{2} \mathrm{~T}$ amount loaded into both types of DMSNs was quantified based on its absorbance at 225 $\mathrm{nm}$ (section $\$ S I-1.3$, Figure SI-3A) and using a calibration curve (section $\$ S I-1.3$, Figure SI-3B). We quantified $1.14 \mathrm{mg}$ and 1.16 $\mathrm{mg}$ of $\mathrm{B}_{2} \mathrm{~T}$ loaded in $2.0 \mathrm{mg}$ of DMSNs-57 and DMSNs-156, respectively. The loading capacities were $570 \mu \mathrm{g} / \mathrm{mg}$ DMSNs for DMSNs-57 and $580 \mu \mathrm{g} / \mathrm{mg}$ DMSNs for DMSNs-156, and the encapsulation efficiencies (EE\%) reached $76 \%$ and $77 \%$, respectively. Regardless the differences in DMSNs sizes, we measured similar loading efficiencies. We attribute this to their close z-potential values and to the equivalent hydrogen bonds and polar interactions with the peptide (37). The high $\mathrm{B}_{2} \mathrm{~T}$ loading capacities obtained are probably related to the strong electrostatic interaction between the anionic DMSNs and the positively charged $\mathrm{B}_{2} \mathrm{~T}$ ( $\mathrm{pI}$ 10.88) in DPBS ( $\mathrm{pH}$ 7.4) and to the DMSNs central-radial pore structures with large surface areas $(17,18)$.

We performed the loading under different conditions (section SSI-1.4) $(38,39)$ to evaluate the impact of ionic strength (Figure SI-4), peptide (cargo) structure (dendrimer vs. linear) (Figure SI-5) and DMSNs charge (Figure SI-6) on the loading efficiency of the DMSNs. We used, for comparison, $168 \mathrm{~nm}$ solid silica nanoparticles (SNSs-168) (Figures SI-4 and SI-5). Results on section SSI-1.4 (Figures SI-4, SI-5, SI-6) displayed that the higher the ionic strength, the more $\mathrm{B}_{2} \mathrm{~T}$ was loaded into all silica nanoparticles. Being DMSNs more efficient than SNSs. The trend was maintained for the dendrimer $\mathrm{B}_{2} \mathrm{~T}$ and a linear control peptide (O PanAsia B epitope B) regardless of DMSNs charge. Up to $5 \times$ ionic strength, DMSNs-156 were more efficiently loading the peptide. Note that within this work the ionic strength was set at $1 \times$. Furthermore, we observed that our synthesized, negatively charged DMSNs were significantly more effective in loading the $\mathrm{B}_{2} \mathrm{~T}$ peptide than their positively charged counterparts (Figure SI-6).

Next, we investigated the $B_{2} T$ release kinetics from the DMSNs. To this end $\mathrm{B}_{2} \mathrm{~T} @ \mathrm{DMSN}$ s were dispersed in a saline buffer ( $1 \times$ DPBS). At given time points, we collected the supernatants after centrifugation, we measured their absorbance at $225 \mathrm{~nm}$ and with help of the calibration curve (Figure SI-3.B), we quantified the amount of $\mathrm{B}_{2} \mathrm{~T}$ released from the DMSNs. Figure 2 shows a sustained release of $\mathrm{B}_{2} \mathrm{~T}$ up to $1000 \mathrm{~h}$ (41 days). After $700 \mathrm{~h}$, the release curve reached a plateau. Both $\mathrm{B}_{2} \mathrm{~T} @ \mathrm{DMSNs}-57$ and $\mathrm{B}_{2} \mathrm{~T} @ \mathrm{DMSN}$-156 showed similar release kinetics. The $\mathrm{B}_{2} \mathrm{~T}$ amount released in $\mathrm{B}_{2} \mathrm{~T} @ \mathrm{DMSNs}-57$ 
A

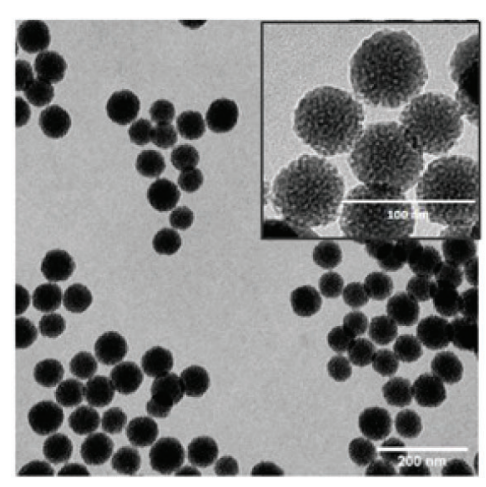

C

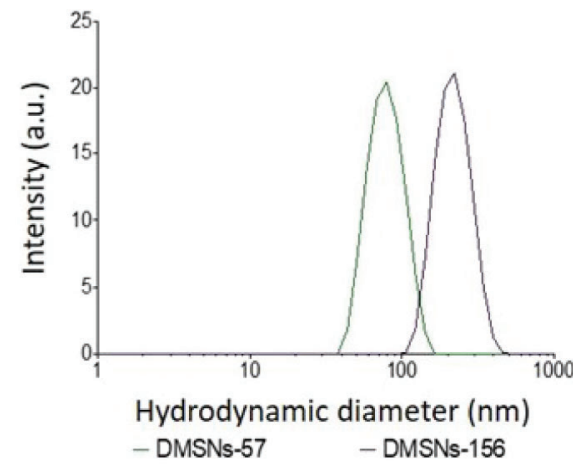

B

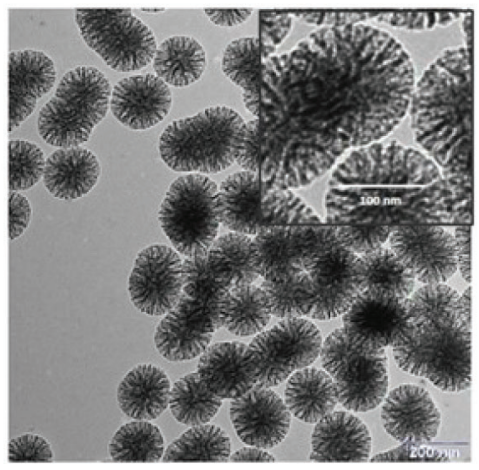

D

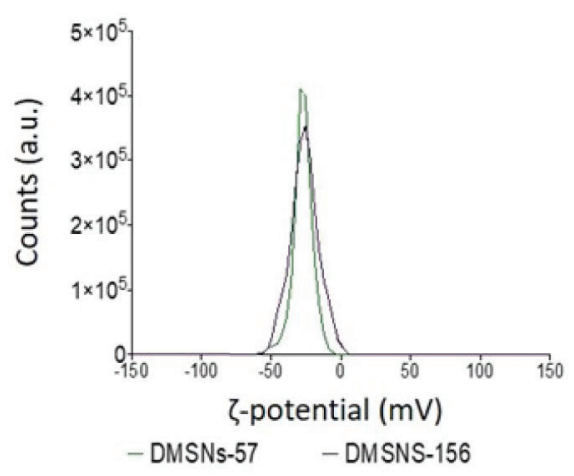

FIGURE 1 | TEM and DLS analysis of DMSNs-57 and DMSNs-156. TEM image of $57 \mathrm{~nm}$ DMSNs (A) and of $156 \mathrm{~nm}$ DMSNs (B). Scale bar, $200 \mathrm{~nm}$. The insets show the DMSNs with higher magnification revealing the dendritic structure. Scale bar, $100 \mathrm{~nm}$. (C) DMSNs-57 and DMSNs-156 hydrodynamic size (75 $\pm 9 \mathrm{~nm}$ and $156 \pm 10 \mathrm{~nm})$ and (D) $\zeta$-potential values (-30.2 and $-37.1 \mathrm{mV})$.

and $\mathrm{B}_{2} \mathrm{~T} @ \mathrm{DMSNs}-156$ corresponds to $23.7 \%(135 \mu \mathrm{g})$ and $22.8 \%$ $(132 \mu \mathrm{g})$ of the total amount loaded.

Albumin is one of the most frequent proteins in physiological fluids and a major component of the protein corona of biomedical nanomaterials dispersed in such fluids (40-44). It is also known that the protein corona formed on nanoparticles is a dynamic system. Following typical nanoparticle behavior, we expected a protein corona around our DMSNs upon their in vivo administration. We therefore wanted to elucidate the impact of the protein corona on the $\mathrm{B}_{2} \mathrm{~T}$ release kinetics (Figure 2). To this end, we dispersed the $\mathrm{B}_{2} \mathrm{~T} @ \mathrm{DMSN}$ in medium containing albumin (BSA $250 \mu \mathrm{g} / \mathrm{ml}$ in DPBS), allowed the DMSNs to build their protein corona and measured the $\mathrm{B}_{2} \mathrm{~T}$ release (section \$SI-1.5) following the procedure described before. We took advantage of the distinct absorption peaks for $\mathrm{B}_{2} \mathrm{~T}$ at $225 \mathrm{~nm}$ (section $\$ S I-1.3$ ) and for albumin at $280 \mathrm{~nm}$ (section $\$ S I-1.5$, Figure SI-7) to build calibration curves. In this case we could also track changes on the protein corona formed around the $\mathrm{B}_{2} \mathrm{~T} @ \mathrm{DMSNs}$. Our methodology enabled the concomitant quantification of the release of both components, $\mathrm{B}_{2} \mathrm{~T}$ and albumin, from the DMSNs to the medium. We validated this technology with HPLC (section $\$ S I-1.5$, Figure SI-8). Then we quantified the $\mathrm{B}_{2} \mathrm{~T}$ release from the protein coated DMSNs (Figure 2) and correlated the results with the amount of albumin released from the protein corona (section $\$ S I-1.5$, Figure SI-9).

After the formation of the protein corona, $\mathrm{B}_{2} \mathrm{~T}$ release increased $158 \%$ on $\mathrm{B}_{2} \mathrm{~T} @ \mathrm{DMSNs}-57$ and $252 \%$ on $\mathrm{B}_{2} \mathrm{~T} @$ DMSNs-156. This corresponds to $61 \%(348 \mu \mathrm{g} / \mathrm{mg})$ and $80 \%$ $(464 \mu \mathrm{g} / \mathrm{mg})$ of the total $\mathrm{B}_{2} \mathrm{~T}$ loaded within $\mathrm{B}_{2} \mathrm{~T} @ \mathrm{DMSNs}-57$ and $\mathrm{B}_{2} \mathrm{~T} @ \mathrm{DMSNs}-156$, respectively. It seems evident, that the presence of BSA significantly enhances $B_{2} T$ release. We ascribed this effect to a competitive interaction towards the DMSNs in favor of BSA resulting in $\mathrm{B}_{2} \mathrm{~T}$ displacement and release $(45,46)$. To prove this, we monitored the changes of BSA concentration in the dispersed medium in the presence of the DMSNs (Figure SI-9). As seen in Figure SI-9, during the first 66.5 hours, both $\mathrm{B}_{2} \mathrm{~T} @ \mathrm{DMSNs}-57$ and $\mathrm{B}_{2} \mathrm{~T} @ \mathrm{DMSNs}-156$ kept absorbing BSA from the medium, probably due to forming BSA protein corona on DMSNs, which resulted in lower BSA concentrations $(<250 \mu \mathrm{g} / \mathrm{mL})$ in the supernatants. Afterwards, the BSA level in both formations kept fluctuating around $250 \mu \mathrm{g} /$ $\mathrm{ml}$ (initial concentration added) which points out to an absence of protein corona around the DMSNs. Although longer 


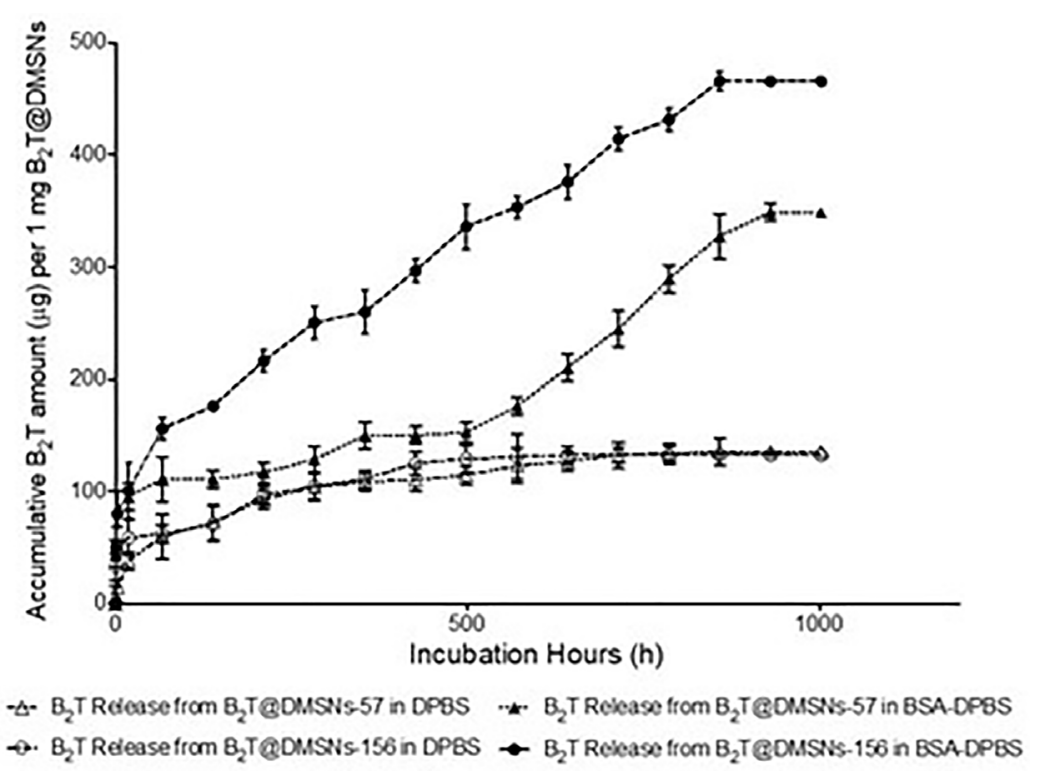

FIGURE 2 | $B_{2}$ T release profiles from $B_{2}$ T@DMSNs-57 and from $B_{2}$ T@DMSNs-156 dispersed in DPBS or BSA-DPBS. After each time point, the supernatants were collected for UV-vis analysis and the pellets were redispersed in the same volume of medium. The procedure was repeated during 1,000 $\mathrm{h}$.

experiments would be required to draw a conclusion, these results may indicate a long-term sustained release promoted by the DMSNs. At any rate, they confirm vaccine release from the DMSNs in physiological complex media as the one in the cell.

\section{Internalization of $\mathrm{B}_{2} \mathrm{~T} @ \mathrm{DMSNs}$ by Macrophages}

Cellular uptake of antigens by innate immune cells provides antigen-processing and subsequent costimulatory signals that are crucial to trigger acquired immune responses, especially for low immunogenic peptide antigens. Macrophage-like RAW 264.7 cells (47) are often used to study cellular responses to microbes and their products (48). We selected this cell model to assess in vitro cellular internalization of our nanoformulations, using $1 \mathrm{mg}$ DMSNs-57 and $1 \mathrm{mg}$ DMSNs-156 loaded with $200 \mu \mathrm{g} \mathrm{B}_{2} \mathrm{~T}$ labeled with a dye (i.e., fluoro- $\mathrm{B}_{2} \mathrm{~T}$ ) (see section $\$ S I-2$ and Figure SI-10). Similar to other nanoparticles (49), cellular uptake of fluoro- $\mathrm{B}_{2} \mathrm{~T} @ \mathrm{DMSN}$ s occurred in a size-dependent manner (Figure 3). The maximum uptake level was observed after $4 \mathrm{~h}$ for the fluoro- $\mathrm{B}_{2} \mathrm{~T} @ \mathrm{DMSNs}-57$ (57 nm size) and after $8 \mathrm{~h}$ for the fluoro- $\mathrm{B}_{2} \mathrm{~T} @ \mathrm{DMSNs}-156$ (156 nm size) (Figures 3A, B, and §SI-2 and Figures SI-11, SI-12 and SI-13). During the first $4 \mathrm{~h}$, the amount of $\mathrm{B}_{2} \mathrm{~T} @ \mathrm{DMSNs}-57$ interacting with the cells was approximately two times the amount of $\mathrm{B}_{2} \mathrm{~T} @ \mathrm{DMSNs}$ 156 (Figure 3B). We can conclude that at least after an acute exposure, the smaller DMSNs-57 are faster internalized by RAW 264.7 cells than larger DMSNs-156. It is noteworthy that after the cellular uptake reached the maximum value, longer incubation times resulted in reduced uptake values. We suppose that it is due to the fast cell growth and division of RAW 264.7 cells (50) which resulted in the "dilution effect" of fluorescence intensity per cell.

\section{Sustained Mice Immunogenicity Provided by $\mathrm{B}_{\mathbf{2}} \mathrm{T} @ \mathrm{DMSNS}$}

We next validated $\mathrm{B}_{2} \mathrm{~T} @ \mathrm{DMSN}$ performance by testing in vivo their immunogenicity. To this end, we performed two sets of vaccination trials in mice (see section \$SI-3 for a detailed description). In both trials, we injected subcutaneously samples containing the same amount of $\mathrm{B}_{2} \mathrm{~T}$ antigen $(100 \mu \mathrm{g})$ at day 0 and boosted with the same dose at day 21. We performed an ELISA to detect specific anti- $\mathrm{B}_{2} \mathrm{~T}$ antibodies in sera collected following the schedule shown in Tables SI-1 and SI-2 (section $\$ S I-2)$. In the first trial (Table SI-1 and Figure 4), mice were vaccinated with $\mathrm{B}_{2} \mathrm{~T} @ M o n t a n i d \mathrm{~T}^{\mathrm{TM}}$ (positive control), B B $_{2}$ @DMSNs-156, and bare DMSNs-156 (negative control). Results in Figure 4 show that $\mathrm{B}_{2} \mathrm{~T} @ \mathrm{DMSN}$ treatment elicits a consistent response with all treated mice, presenting an increase in anti- $\mathrm{B}_{2} \mathrm{~T}$ IgG production values after the boost (day 40). Although the anti$\mathrm{B}_{2} \mathrm{~T}$ IgG level from $\mathrm{B}_{2} \mathrm{~T} @ \mathrm{DMSNs}-156$ is slightly lower than $\mathrm{B}_{2} \mathrm{~T} @$ Montanide, these results confirm that $\mathrm{B}_{2} \mathrm{~T} @ \mathrm{DMSNs}-156$ successfully stimulates anti- $\mathrm{B}_{2} \mathrm{~T}$-specific immune response in mice. On the contrary, as expected, no enhancement of the immune response was found in mice treated with bare DMSNs-156.

Once we confirmed the immunogenic effect of $\mathrm{B}_{2} \mathrm{~T} @ \mathrm{DMSN}$ and considering their long-time sustained release profile obtained in vitro (Figure 2), we performed a second trial (section §SI-2, Table SI-2). In this case, mice vaccinated with either $\mathrm{B}_{2} \mathrm{~T} @ \mathrm{DMSNs}-57$ or B 2 T@DMSNs-156 particle sizes were subjected to a longitudinal analysis of serum-IgG responses up to 80 days. As shown in Figure 5, anti- $\mathrm{B}_{2} \mathrm{~T}$ IgG titers were clearly boosted up among all tested formulations at day 40 , although this time we also detected serum-IgG responses in some mice 
A

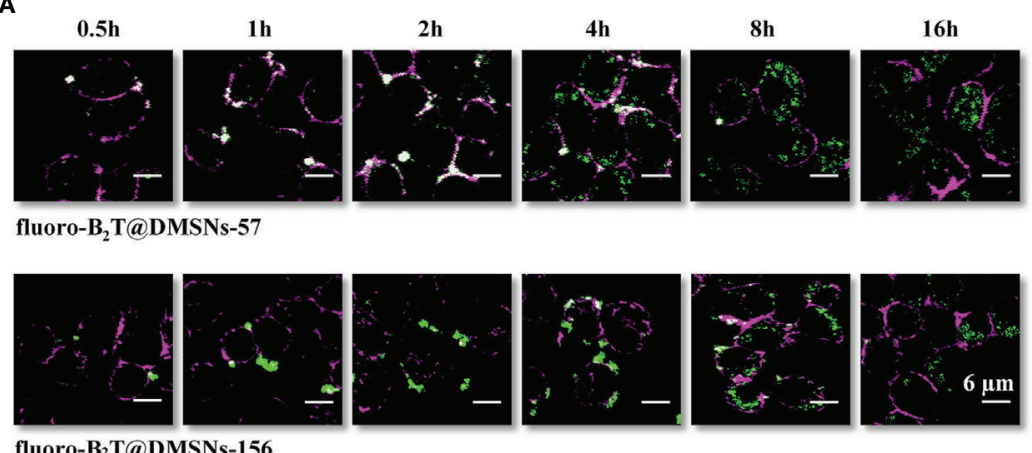

fluoro-B $\mathbf{T} @$ DMSNs-156

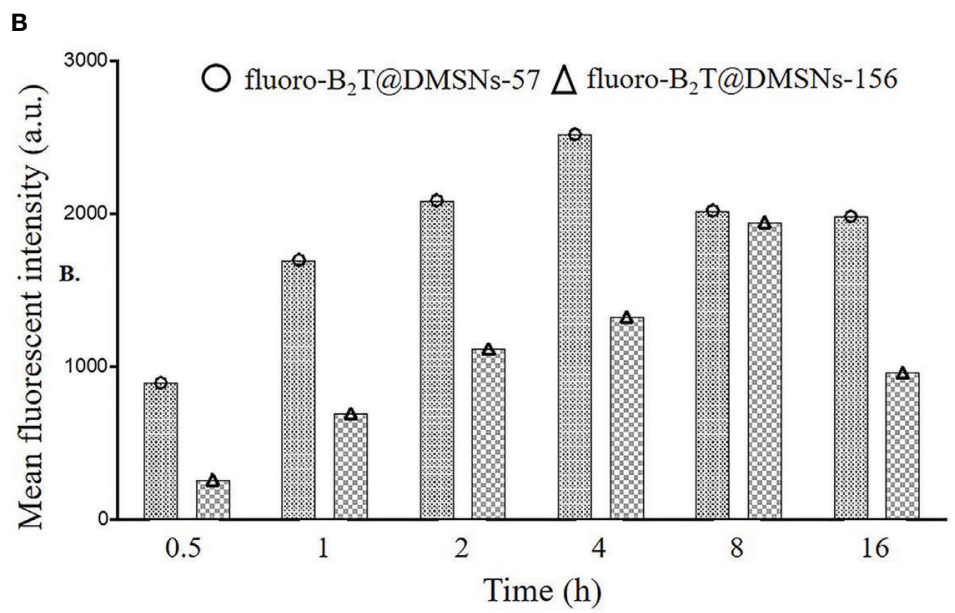

FIGURE 3 | RAW 264.7 macrophage cellular interactions of fluoro-B 2 T@DMSNs-57 and fluoro-B 2 T@DMSNs-156. (A) CLSM images showing a time- and DMSNs size-dependent internalization. (Note: Green correspond to BodiFluor-488 conjugated to the $\mathrm{B}_{2} \mathrm{~T}$ loaded within the DMSNs whereas the magenta color corresponds to the dye, cell mask deep red used to stain the plasma membrane of the cells). (cf. $\$ S I-11$, Figures SI-11, SI-12, and $\mathbf{S I - 1 6 )}$ (B) Flow cytometry analysis of cellular interactions. The columns represent the mean fluorescence intensity of fluoro-B ${ }_{2}$ T@DMSNs-57 and fluoro-B 2 T@DMSNs-156. (cf. §SI-2.3, Figures SI-13).

immunized with $\mathrm{B}_{2}$ T@DMSNs-156 already at day 20 before the boost. We do not have a clear explanation for these different results between trials, so we attribute it to the intrinsic variability of in vivo studies (section $S S I-3$, Figures SI-14, SI-15, and SI-16). B 2 T@DMSNs-57 and B $_{2}$ T@DMSNs-156 showed slightly lower post-boosting titers than the positive control, $\mathrm{B}_{2} \mathrm{~T} @$ Montanide $^{\mathrm{TM}}$. However, in the case of the $\mathrm{B}_{2}$ T@DMSNs-57 mice group, their serum titers increased over time until reaching comparable IgG levels to the positive control group at days 60 and 80 with high consistency among individuals. These results with the DMSNs-57 formulation are in consonance with published works reporting nanoparticle traffic to the draining lymph node in a size-dependent manner, with small $20 \sim 50 \mathrm{~nm}$ nanoparticles being more efficiently drained than bigger ones ( 9 , $23,25)$. We can confirm the efficiency of DMSNs to induce sustained $\mathrm{Ab}$ responses in a size dependent manner comparable to the emulsified version $\mathrm{B}_{2} \mathrm{~T} @$ Montanide ${ }^{\mathrm{TM}}$, pointing to demonstrable adjuvant properties of DMSNs. Finally, it is worth noting that, as not all $\mathrm{B}_{2} \mathrm{~T}$ is released from the DMSNs at day 80 , one could possibly expect a sustained immunogenic effect beyond that time point.

\section{CONCLUSIONS}

Biopharmaceutical companies are now actively focused on the development of sustained release drug delivery systems, in view of their inherent benefits. Sustained release formulations designed to maintain the required therapeutic concentrations over an extended period of time present several advantages over conventional dosage forms, including less frequent drug dose, reduced concentration fluctuations, minimal side effects, reduced healthcare costs, improved efficiency and/or immune responses $(51,52)$. In this context, DMSNs are gaining increasing interest as effective delivery system because they are tunable, exhibit high loading capacity for therapeutic agents, and their release can be controlled. In this work, we evaluate the applicability of these nanocarriers in vaccination and long-term protection using a peptide-based vaccine with 


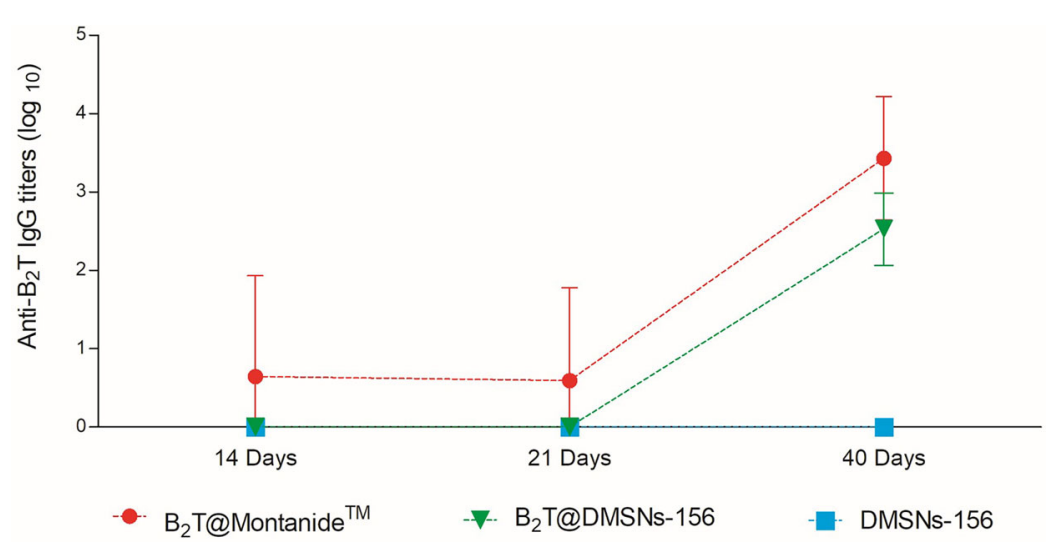

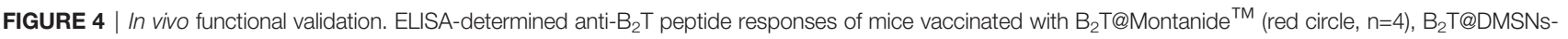
156nm (green down triangle, $\mathrm{n}=6$ ), DMSNs-156nm (blue squares, $\mathrm{n}=4$ ) from sera collected at days 14, 21 (pre-boost) and 40 (post-boost) post-immunization. Each point depicts mean antibody titers (calculated as described in Materials and methods) \pm SD for each group. No individual spontaneous reactivity was observed in the titers determined at day 0. (cf. §SI-3; Table SI-1, and Figures SI-14, SI-15, and SI-16).

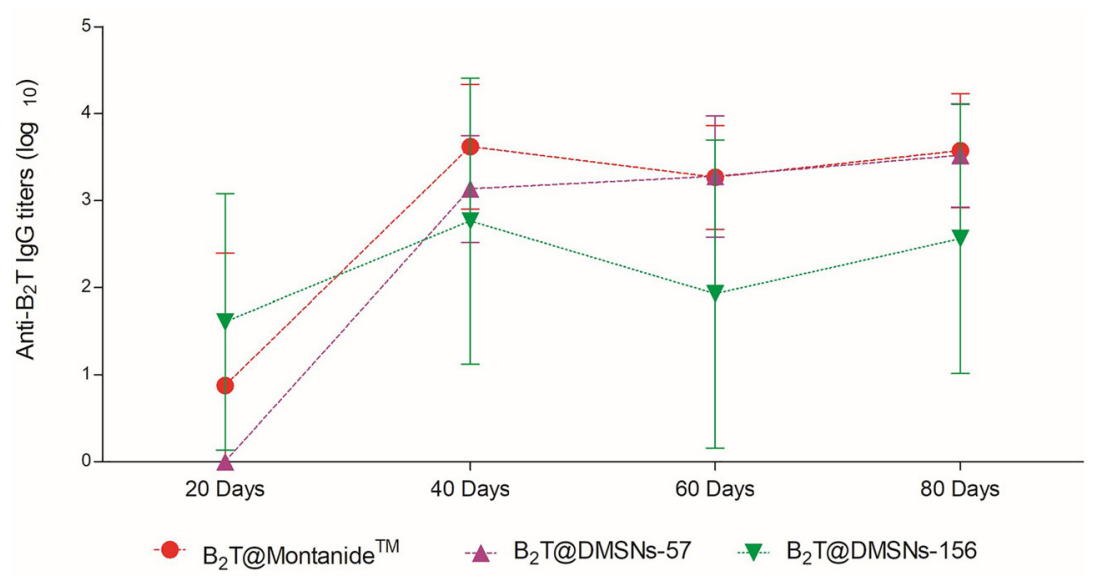

FIGURE 5 | Sustained in vivo immune response performed by the DMSNs. ELISA-determined anti-B ${ }_{2}^{T}$ peptide responses obtained in vaccination trial II (Table SI2) of mice vaccinated with $B_{2} T @ M o n t a n i d T^{T M}$ (red circle, $n=3$ ), $B_{2} T @ D M S N s-57 n m$ (purple up triangle, $n=5$ ) and $B_{2} T @ D M S N s-156 n m(g r e e n$ down triangle, $n=5$ ) from sera collected on the indicated days post-immunization (20, 40, 60, and 80 pi). Each point depicts mean antibody titers (calculated as described in Materials and methods) \pm SD for each group. No individual spontaneous reactivity was observed in the titers determined at day 0. (cf. §SI-3; Table SI-2, and Figures SI-14, SI-15, and SI-16).

previously reported protective immunity against FMDV. Our results demonstrate that DMSNs are colloidally stable and monodisperse, with high loading capacities for a bioactive peptide such as B2T, besides being reported as non-toxic (53-56). The $\mathrm{B}_{2} \mathrm{~T} @ \mathrm{DMSN}$ s resulting formulations present long-term sustained in vitro release properties, enhanced in the presence of BSA. Tracking a fluoro-labeled version of $\mathrm{B}_{2} \mathrm{~T}$ within DMSNs formulations we could observed acute differences (within $16 \mathrm{~h}$ ) in the internalization of the $\mathrm{B}_{2} \mathrm{~T} @ \mathrm{DMSN}$ by macrophage cells in a size dependent manner. Finally, the effectivity of $\mathrm{B}_{2} \mathrm{~T} @ \mathrm{DMSN}$ as nanovaccine was validated in vivo by comparing the inmunogenic response to that of the positive control $\mathrm{B}_{2} \mathrm{~T} @$ Montanide ${ }^{\mathrm{TM}}$. Mice vaccination trials showed that both DMSNs formulations increased specific $\mathrm{B}_{2} \mathrm{~T}$ antibody titers in a similar manner. However, results revealed a trend toward higher antibody titers in the animal group immunized with DMSNs of smaller particle size $(57 \mathrm{~nm})$ in agreement with previous literature $(57,58)$. Taken together, these results indicate that DMSNs is an excellent carrier for peptide vaccine which favors the internalization of the antigen by immune cell. Besides, they also delay or slown down their in vivo release, finally leading to a long-lasting sustained immune response activation. Therefore, DMSNs may be a suitable vaccine delivery system alternative to conventional adjuvanted vaccines not only for whole viruses or protein antigens but also for synthetic peptide-based subunit candidates. 


\section{DATA AVAILABILITY STATEMENT}

The original contributions presented in the study are included in the article/Supplementary Material. Further inquiries can be directed to the corresponding author.

\section{ETHICS STATEMENT}

The animal study was reviewed and approved by DAAM 7463.

\section{AUTHOR CONTRIBUTIONS}

WA contributed to the design of the synthesis study, to data analysis, and wrote the first draft. SD contributed to the design of the in vivo study, and to its data analysis. DA contributed to the design of the in vivo study. PR contributed to the conception and design of the study, to data analysis and wrote the manuscript. All authors contributed to the article and approved the submitted version.

\section{FUNDING}

This research was funded by Spanish Ministry of Science, Innovation and Universities (grants AGL2014-48923-C2 and

\section{REFERENCES}

1. Li W, Joshi MD, Singhania S, Ramsey KH, Murthy AK. Peptide Vaccine: Progress and Challenges. Vaccines (2014) 2:515-36. doi: 10.3390/vaccines2030515

2. Fujita Y, Taguchi H. Nanoparticle-Based Peptide Vaccines. Oxford, United Kingdom; Cambridge, MA: William Andrew is an imprint of Elsevier (2017). doi: 10.1016/B978-0-323-39981-4.00008-7

3. Moynihan KD, Holden RL, Mehta NK, Wang C, Karver MR, Dinter J, et al. Enhancement of Peptide Vaccine Immunogenicity by Increasing Lymphatic Drainage and Boosting Serum Stability. Cancer Immunol Res (2018) 6 (9):1025-38. doi: 10.1158/2326-6066.CIR-17-0607

4. Sesardic D. Synthetic Peptide Vaccines. J Med Microbiol (1993) 39:241-2. doi: $10.18097 /$ pbmc20115701014

5. Blanco E, Andreu D, Sobrino F. Peptide Vaccines Against Foot-and-Mouth Disease Virus. Curr Res Emerg Trends (2017), 317-32. doi: 10.21775/ 9781910190517.13

6. Bezu L, Kepp O, Cerrato G, Pol J, Fucikova J, Spisek R, et al. Trial Watch: Peptide-Based Vaccines in Anticancer Therapy. Oncoimmunology (2018) 7: e1511506. doi: 10.1080/2162402X.2018.1511506

7. Azmi F, Fuaad AAHA, Skwarczynski M, Toth I. Recent Progress in Adjuvant Discovery for Peptide-Based Subunit Vaccines. Hum Vaccines Immunother (2014) 10:778-96. doi: 10.4161/hv.27332

8. Awate S, Babiuk LA, Mutwiri G. Mechanisms of Action of Adjuvants. Front Immunol (2013) 4:1-10. doi: 10.3389/fimmu.2013.00114

9. Chattopadhyay S, Chen JY, Chen HW, Jack Hu CM. Nanoparticle Vaccines Adopting Virus-Like Features for Enhanced Immune Potentiation. Nanotheranostics (2017) 1:244-60. doi: 10.7150/ntno.19796

10. Gregory AE, Titball R, Williamson D. Vaccine Delivery Using Nanoparticles. Front Cell Infect Microbiol (2013) 3:13. doi: 10.3389/fcimb.2013.00013

11. Peek LJ, Middaugh CR, Berkland C. Nanotechnology in Vaccine Delivery. $A d v$ Drug Deliv Rev (2008) 60:915-28. doi: 10.1016/j.addr.2007.05.017

12. Gheibi Hayat SM, Darroudi M. Nanovaccine: A Novel Approach in Immunization. J Cell Physiol (2019) 234:12530-6. doi: 10.1002/jcp.28120
AGL2017-84097-C2-2-R to DA) as well as by Generalitat de Catalunya (grant 2009SGR492 to DA).

\section{ACKNOWLEDGMENTS}

PRG acknowledges The Gneralitat de Catalunya (2017SGR 1054 - AGAUR) and the Ministry of Science, Innovation and Universities (MICINN) and the AEI (AEI-PID2019-106755RBI00, RYC-2012-10059, MDM-2014-0370-04, CTQ2013-45433-P [FEDER], MAT2016-75362-C3-2-R, AEI-SAF2015-73052-EXP) for financial support. PR and WA thank the China Scholarship Council (201694910800) for the PhD fellowship of WA. The ICTS "NANOBIOSIS", and particularly the Custom Antibody Service (CAbS, IQAC-CSIC, CIBER-BBN), is acknowledged for the assistance and support on animal experiments. We thank the UPF/CRG Flow Cytometry Unit (PRBB, Barcelona) for help with the flow cytometry analysis.

\section{SUPPLEMENTARY MATERIAL}

The Supplementary Material for this article can be found online at: https://www.frontiersin.org/articles/10.3389/fimmu.2021. 684612/full\#supplementary-material
13. Zhao L, Seth A, Wibowo N, Zhao C-XX, Mitter N, Yu C, et al. Nanoparticle Vaccines. Vaccine (2014) 32:327-37. doi: 10.1016/j.vaccine.2013.11.069

14. Fenollosa R, Garcia-Rico E, Alvarez S, Alvarez R, Yu X, Rodriguez I, et al. Silicon Particles as Trojan Horses for Potential Cancer Therapy. J Nanobiotechnol (2014) 12:1-10. doi: 10.1186/s12951-014-0035-7

15. Rivera Gil P, Hühn D, del Mercato LL, Sasse D, Parak WJ. Nanopharmacy: Inorganic Nanoscale Devices as Vectors and Active Compounds. Pharmacol Res (2010) 62:115-25. doi: 10.1016/j.phrs.2010.01.009

16. Taki A, Smooker P. Small Wonders-The Use of Nanoparticles for Delivering Antigen. Vaccines (2015) 3:638-61. doi: 10.3390/vaccines3030638

17. Yang Y, Bernardi S, Song H, Zhang J, Yu M, Reid JC, et al. Anion Assisted Synthesis of Large Pore Hollow Dendritic Mesoporous Organosilica Nanoparticles: Understanding the Composition Gradient. Chem Mater (2016) 28:704-7. doi: 10.1021/acs.chemmater.5b03963

18. Lu Y, Yang Y, Gu Z, Zhang J, Song H, Xiang G, et al. Glutathione-Depletion Mesoporous Organosilica Nanoparticles as a Self-Adjuvant and Co-delivery Platform for Enhanced Cancer Immunotherapy. Biomaterials (2018) 175:8292. doi: 10.1016/j.biomaterials.2018.05.025

19. Cha BG, Jeong JH, Kim J. Extra-Large Pore Mesoporous Silica Nanoparticles Enabling Co-Delivery of High Amounts of Protein Antigen and Toll-Like Receptor 9 Agonist for Enhanced Cancer Vaccine Efficacy. ACS Cent Sci (2018) 4:484-92. doi: 10.1021/acscentsci.8b00035

20. Shen D, Yang J, Li X, Zhou L, Zhang R, Li W, et al. Biphase Stratification Approach to Three-Dimensional Dendritic Biodegradable Mesoporous Silica Nanospheres. Nano Lett (2014) 14:923-32. doi: 10.1021/nl404316v

21. Mody KT, Popat A, Mahony D, Cavallaro AS, Yu C, Mitter N. Mesoporous Silica Nanoparticles as Antigen Carriers and Adjuvants for Vaccine Delivery. Nanoscale (2013) 5:5167-79. doi: 10.1039/c3nr00357d

22. Xu C, Lei C, Yu C. Mesoporous Silica Nanoparticles for Protein Protection and Delivery. Front Chem (2019) 7:290. doi: 10.3389/fchem.2019.00290

23. Manolova V, Flace A, Bauer M, Schwarz K, Saudan P, Bachmann MF. Nanoparticles Target Distinct Dendritic Cell Populations According to Their Size. Eur J Immunol (2008) 38:1404-13. doi: 10.1002/eji.200737984 
24. Bachmann MF, Jennings GT. Vaccine Delivery: A Matter of Size, Geometry, Kinetics and Molecular Patterns. Nat Rev Immunol (2010) 10:787-96. doi: 10.1038/nri2868

25. Reddy ST, van der Vlies AJ, Simeoni E, Angeli V, Randolph GJ, O’Neil CP, et al. Exploiting Lymphatic Transport and Complement Activation in Nanoparticle Vaccines. Nat Biotechnol (2007) 25:1159-64. doi: 10.1038/nbt1332

26. de Pádua Oliveira DC, de Barros ALB, Belardi RM, de Goes AM, de Oliveira Souza BK, Soares DCF. Mesoporous Silica Nanoparticles as a Potential Vaccine Adjuvant Against Schistosoma Mansoni. J Drug Deliv Sci Technol (2016) 35:234-40. doi: 10.1016/J.JDDST.2016.07.002

27. Virginio VG, Bandeira NC, Leal FMDA, Lancellotti M, Zaha A, Ferreira HB. Assessment of the Adjuvant Activity of Mesoporous Silica Nanoparticles in Recombinant Mycoplasma Hyopneumoniae Antigen Vaccines. Heliyon (2017) 3(1):e00225. doi: 10.1016/J.HELIYON.2016.E00225

28. Zhao L, Mahony D, Cavallaro AS, Zhang B, Zhang J, Deringer JR, et al. Immunogenicity of Outer Membrane Proteins VirB9-1 and VirB9-2, A Novel Nanovaccine Against Anaplasma Marginale. PloS One (2016) 11:e0154295. doi: 10.1371/journal.pone.0154295

29. Bai M, Dong H, Su X, Jin Y, Sun S, Zhang Y, et al. Hollow Mesoporous Silica Nanoparticles as Delivery Vehicle of Foot-and-Mouth Disease Virus-Like Particles Induce Persistent Immune Responses in Guinea Pigs. J Med Virol (2019) 91:941-8. doi: 10.1002/jmv.25417

30. Blanco E, Cubillos C, Moreno N, Bárcena J, de la Torre BG, Andreu D, et al. B Epitope Multiplicity and B/T Epitope Orientation Influence Immunogenicity of Foot-and-Mouth Disease Peptide Vaccines. Clin Dev Immunol (2013) 2013. doi: $10.1155 / 2013 / 475960$

31. Blanco E, Guerra B, de la Torre BG, Defaus S, Dekker A, Andreu D, et al. Full Protection of Swine Against Foot-and-Mouth Disease by a Bivalent B-Cell Epitope Dendrimer Peptide. Antiviral Res (2016) 129:74-80. doi: 10.1016/j.antiviral.2016.03.005

32. de León P, Cañas-Arranz R, Defaus S, Torres E, Forner M, Bustos MJ, et al. Swine T-Cells and Specific Antibodies Evoked by Peptide Dendrimers Displaying Different FMDV T-Cell Epitopes. Front Immunol (2021) 11:621537. doi: 10.3389/fimmu.2020.621537

33. Defaus S, Forner M, Cañas-Arranz R, de León P, Bustos MJ, Rodríguez-Pulido $\mathrm{M}$, et al. Designing Functionally Versatile, Highly Immunogenic PeptideBased Multiepitopic Vaccines Against Foot-and-Mouth Disease Virus. Vaccines (Basel) (2020) 8(3):406. doi: 10.3390/vaccines8030406

34. Wu Y, Ellis RD, Shaffer D, Fontes E, Malkin EM, Mahanty S, et al. Phase 1 Trial of Malaria Transmission Blocking Vaccine Candidates Pfs 25 and Pvs 25 Formulated With Montanide ISA 51. PloS One (2008) 3(7):e2636. doi: 10.1371/journal.pone.0002636

35. Reed SG, Bertholet S, Coler RN, Friede M. New Horizons in Adjuvants for Vaccine Development. Trends Immunol (2009) 30:23-32. doi: 10.1016/j.it.2008.09.006

36. Lin YS, Haynes CL. Synthesis and Characterization of Biocompatible and Size-Tunable Multifunctional Porous Silica Nanoparticles. Chem Mater (2009) 21:3979-86. doi: 10.1021/cm901259n

37. Patwardhan SV, Emami FS, Berry RJ, Jones SE, Naik RR, Deschaume O, et al. Chemistry of Aqueous Silica Nanoparticle Surfaces and the Mechanism of Selective Peptide Adsorption. J Am Chem Soc (2012) 134(14):6244-56. doi: $10.1021 /$ ja211307u

38. Rivera-Gil P, Jimenez De Aberasturi D, Wulf V, Pelaz B, Del Pino P, Zhao Y, et al. The Challenge to Relate the Physicochemical Properties of Colloidal Nanoparticles to Their Cytotoxicity. Acc Chem Res (2013) 46:743-9. doi: $10.1021 /$ ar300039j

39. Schweiger C, Hartmann R, Zhang F, Parak WJ, Kissel TH, Rivera-Gil P. Quantification of the Internalization Patterns of Superparamagnetic Iron Oxide Nanoparticles With Opposite Charge. J Nanobiotechnol (2012) 10:28. doi: 10.1186/1477-3155-10-28

40. Zamora-Perez P, Tsoutsi D, Xu R, Rivera-Gil P. Hyperspectral-Enhanced Dark Field Microscopy for Single and Collective Nanoparticle Characterization in Biological Environments. Mater (Basel) (2018) 11 (2):243. doi: 10.3390/ma11020243

41. Mahmoudi M, Meng J, Xue X, Liang XJ, Rahman M, Pfeiffer C, et al. Interaction of Stable Colloidal Nanoparticles With Cellular Membranes. Biotechnol Adv (2014) 32:679-92. doi: 10.1016/j.biotechadv.2013.11.012

42. Chanana M, Rivera-Gil P, Correa-Duarte MA, Liz-Marzán LM, Parak WJ. Physicochemical Properties of Protein-Coated Gold Nanoparticles in Biological Fluids and Cells Before and After Proteolytic Digestion, Angew. Chemie - Int Ed (2013) 52:4179-83. doi: 10.1002/anie.201208019
43. Bros M, Nuhn L, Simon J, Moll L, Mailänder V, Landfester K, et al. The Protein Corona as a Confounding Variable of Nanoparticle-Mediated Targeted Vaccine Delivery. Front Immunol (2018) 9:1760. doi: 10.3389/ fimmu.2018.01760

44. Ge C, Tian J, Zhao Y, Chen C, Zhou R, Chai Z. Towards Understanding of Nanoparticle-Protein Corona. Arch Toxicol (2015) 89:519-39. doi: 10.1007/ s00204-015-1458-0

45. Ozboyaci M, Kokh DB, Corni S, Wade RC. Modeling and Simulation of Protein-Surface Interactions: Achievements and Challenges. Q Rev Biophys 49 (2016) 49:e4. doi: 10.1017/S0033583515000256

46. Ge C, Du J, Zhao L, Wang L, Liu Y, Li D, et al. Binding of Blood Proteins to Carbon Nanotubes Reduces Cytotoxicity. Proc Natl Acad Sci USA (2011) 108:16968-73. doi: 10.1073/pnas.1105270108

47. Hartley JW, Evans LH, Green KY, Naghashfar Z, Macias AR, Zerfas PM, et al. Expression of Infectious Murine Leukemia Viruses by RAW264.7 Cells, a Potential Complication for Studies With a Widely Used Mouse Macrophage Cell Line. Retrovirology (2008) 5:6-11. doi: 10.1186/1742-4690-5-1

48. Berghaus LJ, Moore JN, Hurley DJ, Vandenplas ML, Fortes BP, Wolfert MA, et al. Innate Immune Responses of Primary Murine Macrophage-Lineage Cells and RAW 264.7 Cells to Ligands of Toll-Like Receptors 2, 3, and 4. Comp Immunol Microbiol Infect Dis (2010) 33:443-54. doi: 10.1016/j.cimid.2009.07.001

49. Kastl L, Sasse D, Wulf V, Hartmann R, Mircheski J, Ranke C, et al. Multiple Internalization Pathways of Polyelectrolyte Multilayer Capsules Into Mammalian Cells. ACS Nano (2013) 7:6605-18. doi: 10.1021/nn306032k

50. Assanga I. Cell Growth Curves for Different Cell Lines and Their Relationship With Biological Activities. Int J Biotechnol Mol Biol Res (2013) 4:60-70. doi: 10.5897/ijbmbr2013.0154

51. Demento SL, Cui W, Criscione JM, Stern E, Tulipan J, Kaech SM, et al. Role of Sustained Antigen Release From Nanoparticle Vaccines in Shaping the T Cell Memory Phenotype. Biomaterials (2012) 33:4957-64. doi: 10.1016/ j.biomaterials.2012.03.041

52. Men Y, Gander B, Merkle HP, Corradin G. Induction of Sustained and Elevated Immune Responses to Weakly Immunogenic Synthetic Malarial Peptides by Encapsulation in Biodegradable Polymer Microspheres. Vaccine (1996) 14:1442-50. doi: 10.1016/S0264-410X(96)00074-6

53. Liu T, Li L, Teng X, Huang X, Liu H, Chen D, et al. Single and Repeated Dose Toxicity of Mesoporous Hollow Silica Nanoparticles in Intravenously Exposed Mice. Biomaterials (2011) 32:1657-68. doi: 10.1016/ j.biomaterials.2010.10.035

54. Fu C, Liu T, Li L, Liu H, Chen D, Tang F. The Absorption, Distribution, Excretion and Toxicity of Mesoporous Silica Nanoparticles in Mice Following Different Exposure Routes. Biomaterials (2013) 34:2565-75. doi: 10.1016/ j.biomaterials.2012.12.043

55. He X, Nie H, Wang K, Tan W, Wu X, Zhang P. In Vivo Study of Biodistribution and Urinary Excretion of Surface-Modified Silica Nanoparticles. Anal Chem (2008) 80:9597-603. doi: 10.1021/ac801882g

56. He Q, Zhang Z, Gao F, Li Y, Shi J. In Vivo Biodistribution and Urinary Excretion of Mesoporous Silica Nanoparticles: Effects of Particle Size and Pegylation. Small (2011) 7:271-80. doi: 10.1002/smll.201001459

57. Toda T, Yoshino S. Enhancement of Ovalbumin-Specific Th1, Th2, and Th17 Immune Responses by Amorphous Silica Nanoparticles. Int J Immunopathol Pharmacol (2016) 29:408-20. doi: 10.1177/ 0394632016656192

58. An M, Li M, Xi J, Liu H. Silica Nanoparticle as a Lymph Node Targeting Platform for Vaccine Delivery. ACS Appl Mater Interfaces (2017) 9:23466-75. doi: 10.1021/acsami.7b06024

Conflict of Interest: The authors declare that the research was conducted in the absence of any commercial or financial relationships that could be construed as a potential conflict of interest.

Copyright (C) 2021 An, Defaus, Andreu and Rivera-Gil. This is an open-access article distributed under the terms of the Creative Commons Attribution License (CC BY). The use, distribution or reproduction in other forums is permitted, provided the original author(s) and the copyright owner(s) are credited and that the original publication in this journal is cited, in accordance with accepted academic practice. No use, distribution or reproduction is permitted which does not comply with these terms. 